\title{
FERTILIZING TREATMENT OF SOYBEAN ANJASMORO VARIETIES ON RAINFED RICE FIELD IN WATER SHORTAGES AREAS OF PIDIE REGENCY
}

\author{
Helmi $^{1)}$, Munawar Khalii ${ }^{1}$, Ilyas ${ }^{1)}$, Teuku Makmur ${ }^{2}$, Akhmad Baihaqii ${ }^{2,3)}$ dan Edy Marsudi ${ }^{2)}$ \\ ${ }^{1}$ Program Studi Ilmu Tanah Fakultas Pertanian Universitas Syiah Kuala \\ ${ }^{2}$ Program Studi Agribisnis Fakultas Pertanian Universitas Syiah Kuala \\ ${ }^{3}$ Pusat Riset Pembangunan Pedesaan dan Pertanian Berkelanjutan Universitas Syiah Kuala
}

\section{Article Info}

Article history:

Received

06/15/2021

Received in revised

06/16/2021

Accepted

$06 / 17 / 2021$

\begin{abstract}
Appropriate fertilization in the cultivation of high-yielding varieties has a great opportunity to increase soybean production, especially in soybean centers where areas lack water and ex-paddy fields. An assessment was conducted in Ujong Pie Village, Muara Tiga District, Pidie Regency during the 2020 dry season. The study demonstrated the use of appropriate cultivation technology and superior varieties of Anjasmoro soybean. Plants are managed with integrated crop management (PTT). The land used is land that was previously used for rice planting activities. The study applied five treatments, namely the former fertilized N (P1), K (P2), P (P3), and NPK (P4), as well as the pattern of farmers as control (P5). Pest and disease control is carried out with the principle of IPM. The variables measured were the growth rate of plants and their production components. The results obtained showed that the average plant height during the vegetative period at locations P4 and P5 $(\mathrm{P}<0.05)$ was higher than those who received other treatments. The maximum growth (height) of plants that received the treatment were $56.33 \mathrm{~cm}$ and $54.66 \mathrm{~cm}$. The highest average number of pods per plant occurred in plot P5 and then in P4, 16.50 and 15.00 pods per plant, respectively. The highest average seed production per plant was achieved in plot P5 (18.4 g/plant) and followed by plot P4 (17.13 g/plant) or converted in hectares with an average of $1.82 \mathrm{t} / \mathrm{ha}$ and $1,50 \mathrm{t} / \mathrm{ha}$
\end{abstract}

Keywords: Balanced fertilization, soybean varieties, rainfed rice field

\section{PERLAKUAN PEMUPUKAN BUDIDAYA KEDELAI VARIETAS ANJASMORO PADA LAHAN SAWAH TADAH HUJAN DI WILAYAH KEKURANGAN AIR KABUPATEN PIDIE}

\begin{abstract}
Abstrak
Pemupukan yang tepat pada budidaya varietas unggul berpeluang besar untuk meningkatkan produksi kedelai, terutama di sentra-sentra kedelai yang wilayahnya kekurangan air dan lahan bekas tanaman padi. Suatu pengkajian telah dilakukan di Gampong Ujong Pie, Kecamatan Muara Tiga, Kabupaten Pidie pada musim kemarau 2020. Pengkajian mendemonstrasikan penggunaan teknologi budidaya tepat guna dan varietas unggul kedelai Anjasmoro. Tanaman dikelola dengan pengelolaan tanaman terpadu (PTT). Lahan yang digunakan adalah lahan yang sebelumnya digunakan untuk kegiatan penanaman padi. Pengkajian menerapkan lima perlakuan yaitu bekas dipupuk $\mathrm{N}\left(\mathrm{P}_{1}\right), \mathrm{K}\left(\mathrm{P}_{2}\right), \mathrm{P}\left(\mathrm{P}_{3}\right)$, dan NPK $\left(\mathrm{P}_{4}\right)$, serta pola petani sebagai kontrol $\left(\mathrm{P}_{5}\right)$. Pengendalian hama penyakit dilakukan dengan prinsip PHT. Variabel yang diukur adalah tingkat pertumbuhan tanaman dan komponen produksinya. Hasil yang diperoleh menunjukkan bahwa rata-rata tinggi tanaman pada masa vegetatif pada lokasi $\mathrm{P}_{4}$ dan $\mathrm{P}_{5}(\mathrm{P}<0,05)$ dari yang mendapat perlakuan lainnya. Pertumbuhan maksimum (tinggi) tanaman yang mendapat perlakuan tersebut adalah $56,33 \mathrm{~cm}$ dan $54,66 \mathrm{~cm}$. Rata-rata jumlah polong per tanaman tertinggi terjadi pada plot $\mathrm{P}_{5}$ kemudian pada $\mathrm{P}_{4}$, masingmasing 16,50 dan 15,00 polong per tanaman. Rata- rata produksi biji per tanaman tertinggi dicapai pada plot $\mathrm{P}_{5}(18,4 \mathrm{~g} / \mathrm{tanaman})$ dan diikuti pada plot $\mathrm{P}_{4}(17,13 \mathrm{~g} / \mathrm{tanaman})$ atau $\mathrm{d}$ konversi dalam hektar rata-rata mencapai $1,82 \mathrm{t} / \mathrm{ha}$ dan $1,5 \mathrm{t} / \mathrm{ha}$.

Kata kunci : Pemupukan berimbang, varietas kedelai, sawah tadah hujan.
\end{abstract}




\section{PENDAHULUAN}

Kedelai (Glycine max L. Merrill) pada umumnya ditanam di lahan tegal ataupun lahan sawah tadah hujan, sedangkan untuk tanah sawah irigasi dapat ditanam pada musim kemarau. Komoditi kedelai saat ini mempunyai prospek cukup baik, namun masih kurang mendapat perhatian. Hal tersebut diduga disebabkan oleh tingkat produksi dankeuntungannya masih rendah. Secara umum, faktor-faktor penyebab rendahnya hasil kedelai antara lain adalah : kurang tersedianya benih bermutu dan varietas unggul, tanaman sering mengalami kekeringan atau kelebihan air, cara pengelolaan tanaman belum optimal, gangguan gulma dan hama penyakit, serta kendala sosial ekonomis (Budhi Santoso et al., 1993; Sunarsedyono et al., 2000).

Dibandingkan tanaman kacangkacangan lain, kedelai memiliki kelebihan, ditinjau dari segi agronomis maupun ekonomis, yaitu (1) toleran kekeringan, (2) hama dan penyakit yang menyerang kedelai relatif sedikit, (3) dapat dipanen genjah umur 60-70 HST, (4) dapat ditanam pada tanah yang kurang subur/kurang air dan cara budidaya yang mudah, (5) resiko kegagalan panen secara total adalah kecil, (6) harga jual relatif stabil, dan (7) dapat dikonsumsi langsung oleh petani dengan cara pengolahan yang mudah. Penggunaan input produksi untuk kedelai pada umumnya sangat minimal, karena petani menanam kedelai dengan cara yang masih sederhana tanpa pengolahan tanah, benih disebar, penyiangan minimal, dan sedikit dilakukan pengendalian hama. Walaupun demikian, perlakuan tersebut mengakibatkan produksi di tingkat petani rendah (1,2 ton/ha), sementara dari hasil percobaan bisa mencapai 1,82,3 ton/ha. (Sumarno, 1992).

Oleh karenanya sangat cocok dikembangkan di lahan kering dengan iklim kering. Pengembangan kedelai di daerah baru dengan agroklimat seperti itu juga sangat menjanjikan (Astanto Kasno dan Trustinah Sutarman, 1992).

Indonesia sebenarnya termasuk negara penghasil utama kedelai di dunia walaupun masih jauh di bawah Negara India, namun Indonesia sejak tahun delapan puluhan sudah bisa mengimport kedelai antara 1000 hingga 20.000 ton/tahun. Jawa Tengah merupakan penghasil ke tiga nasional setelah Jawa Timur (30\%), Sulawesi Selatan (20\%) dan Jawa Tengah (15\%). Kondisi ini masih bisa ditingkatkan jika dilakukan budidaya secara optimal.

Kabupaten Pidie merupakan salah satu daerah penghasil kedelai di Aceh. Umumnya kedelai ditanam pada musim kering di lahan sawah, tetapi masih banyak juga lahan-lahan yang diberakan sehingga produktivitas di wilayah ini tidak optimal. Salah satu upaya untuk mengoptimalkan sumberdaya lahan, maka perlu dicari varietas unggul yang cocok untuk sentra-sentra produksi kedelai

Pengkajian ini mendemonstrasikan penggunaan teknologi budidaya tepat guna dan varietas unggul kedelai untuk lokasi 
spesifik khususnya daerah yang kekurangan air. Diharapkan jangka panjangnya teknologi dan varietas ini dapat diadopsi oleh petani secara luas, sehingga dapat meningkatkan produk tivitas dan produksi kedelai di wilayah yang kekurangan air.

\section{METODE PENELITIAN}

\section{Waktu dan Tempat Penelitian}

Pengkajian dilakukan di Desa Kluwan, Kecamatan Penawangan, Kabupaten Pidiepada musim kemarau 2007, pada saat penanaman saluran air sudah ditutup sehingga lokasi dalam kondisi kekurangan air. Pengkajian dilakukan melalui pendekatan model PTT, dengan melibatkan partisipatif petani Adapun komponen teknologi yang diterapkan adalah sebagai berikut (Tabel 1). Penelitian telah dilaksanakan pada Maret hingga September 2020 di UPT Laboratorium Dasar Universitas Samudra Langsa. Sampel O. niloticus Segar dikoleksi dari tambak petani desa Sungai Pauh Tanjung Langsa Barat, kota Langsa. Adapun koleksi sampel daun temurui (Murraya Koenigii L. Spreng) di peroleh dari kota Langsa.

\section{Alat dan Bahan}

Lahan yang digunakan merupakan lahan yang sebelumnya digunakan untuk omission plot padi yang berada di tiga lahan petani sebagai ulangan, sehingga ada lima plot perlakuan yang membedakan yaitu bekas dipupuk N, K, P dan NPK, serta pupuk pola petani sebagai kontrol. Masing-masing plot berukuran 5 m X 5 m. Dalam pertumbuhannya tanaman tanpa diberi pupuk kimia hanya ditambahkan dengan penyemprotan pupuk daun dengan dosis $2 \mathrm{ml} / \mathrm{l}$ air. Pengendalian hama penyakit dilakukan dengan prinsip PHT. Variabel yang diukur meliputi keragaan pertumbuhan dan komponen produksi.

Tabel 1. Perlakuan yang diterapkan dalam pengkajian

\begin{tabular}{ll}
\hline \multicolumn{1}{c}{$\begin{array}{c}\text { Introduksi } \\
\text { teknologi } \\
\text { berumur } \\
\text { Varietas }\end{array}$} & \multicolumn{1}{c}{ Keterangan } \\
& $\begin{array}{l}\text { Anjasmoro } \\
30 \mathrm{~cm} \mathrm{X} \mathrm{20} \mathrm{cm}\end{array}$ \\
Jarak tanam & $2 \mathrm{X}$, fase vegetatif dan \\
Penyiangan & generatif \\
Pengairan & $1 \mathrm{X}$, sebelum berbunga \\
Panen & Umur panen 64-66 HST \\
\hline
\end{tabular}

Lahan yang digunakan merupakan lahan yang sebelumnya digunakan untuk omission plot padi yang berada di tiga lahan petani sebagai ulangan, sehingga ada lima plot perlakuan yang membedakan yaitu bekas dipupuk N, K, P dan NPK, serta pupuk pola petani sebagai kontrol. Masingmasing plot berukuran $5 \mathrm{~m} \mathrm{X} 5 \mathrm{~m}$. Dalam pertumbuhannya tanaman tanpa diberi pupuk kimia hanya ditambahkan dengan penyemprotan pupuk daun dengan dosis $2 \mathrm{ml} / \mathrm{l}$ air. Pengendalian hama penyakit dilakukan dengan prinsip PHT. Variabel yang diukur meliputi keragaan pertumbuhan dan komponen produksi.

\section{HASIL DAN PEMBAHASAN}

Penanaman kedelai pada pengkajian ini dilakukan pada bulan Juni 2020 yaitu setelah lahan digunakan untuk pertanaman omission plot padi, 
sehingga musim panen kedelai masih jatuh pada musim kemarau pada bulan awal September 2020. Kendala yang dialami pada waktu pertanaman kedelai adalah cuaca yang sangat panas dan sulit air, sehingga kondisi benar-benar kering. Pada awal pertumbuhan, prosentase daya tumbuh kedelai sangat bagus yaitu rata-rata diatas $95 \%$. Hal ini karena benih yang ditanam masih tergolong benih sumber yang sudah jelas diketahui daya tumbuhnya baik. Seperti pada umumnya bahwa kualitas benih sangat menentukan terhadap pertumbuhan selanjutnya dan akan berdampak pada produksi.

Tabel l. Keraggan nata-ata tinggit tanaman pada fase vegetatifi dan fase generatif Anijasmoro pada musim kering 2020

\begin{tabular}{ccccc}
\hline & & \multicolumn{3}{c}{ Unur tanaman (HST) } \\
\cline { 3 - 5 } No. Perlakuan & $\begin{array}{c}\text { Perlakuan (plot belas } \\
\text { pemupukan) }\end{array}$ & 20 & 40 & 60 \\
\hline $\mathrm{P}_{1}$ & $\mathrm{NP}$ & 11,79 & 19,76 & 53,86 \\
$\mathrm{P}_{2}$ & $\mathrm{NK}$ & 11,13 & 19,21 & 51,46 \\
$\mathrm{P}_{3}$ & $\mathrm{PK}$ & 10,43 & 18,09 & 49,46 \\
$\mathrm{P}_{4}$ & $\mathrm{NPK}$ & 12,68 & 21,90 & 56,33 \\
$\mathrm{P}_{5}$ & Pola petani & 11,83 & 21,28 & 54,60 \\
\hline
\end{tabular}

Keragaan pertumbuhan tinggi tanaman pada fase vegetatif umur 21 HST dan 35 HST menunjukkan bahwa rata-rata tinggi tanaman kedelai pada lokasi/plot bekas perlakuan pupuk NPK dan pemupukan sesuai pola petani menunjukkan keragaan pertumbuhan yang lebih baik (Gambar 1 dan Tabel 1) dilihat dari tampilannya lebih tinggi dibanding pada plot yang lain. Hal yang sama juga terjadi pada fase generatif umur 54 HST yaitu tinggi maksimum dicapai pada plot bekas perlakuan pupuk NPK dan pemupukan pola petani dengan tinggi maksimum masingmasing 56,3 $\mathrm{cm}$ dan 54,6 cm (Gambar 1). Hal ini menunjukkan bahwa meskipun kedelai toleran terhadap kekeringan, tetapi tanggap tanaman terhadap pemupukan (dalam hal ini residu pemupukan) sangat baik. Di lahan vertisol, kedelai yang ditanam setelah padi kurang tanggap pemupukan K. Dengan teknologi budidaya tanpa olah tanah (TOT) dan tanpa pupuk $\mathrm{P}$ dan $\mathrm{K}$, tanaman memberi hasil cukup tinggi, berkisar antara 1,2 - 1,8 ton/ha. Dengan demikian terjadi efisiensi penggunaan sarana produksi dan tenaga kerja (Astanto Kasno et al., 2002)

Ther instiont

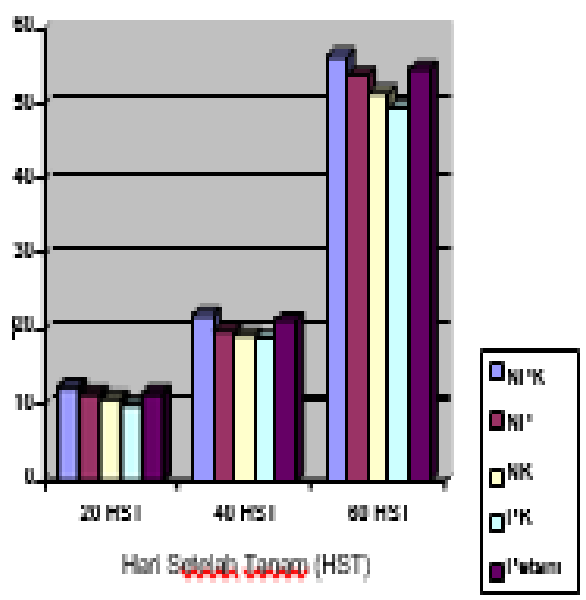

Gambar 1. Rata-rata tinggi tanaman kedelai pada lokasi/plot bekas perlakuan pupuk NPK dan pemupukan sesuai pola petani

\section{Komponen Produksi}

Hasil komponen produksi yang meliputi jumlah polong per tanaman, panjang polong, jumlah biji per 
polong dan produksi kedelai tertera pada gambar 2, 3, 4 dan 5. Dari hasil pengamatan jumlah polong per tanaman (Gambar 2) menunjukkan bahwa rata-rata jumlah polong pertanaman pada semua plot berkisar antara 11,66 hingga 18 buah. Jumlah polong terbanyak 18 buah/tanaman dicapai pada plot bekas pemupukan dengan pola petani, selanjutnya 16,66 dicapai pada plot bekas perlakuan pupuk NPK.

a. Jumlah polong per tanaman

Jumlah golong

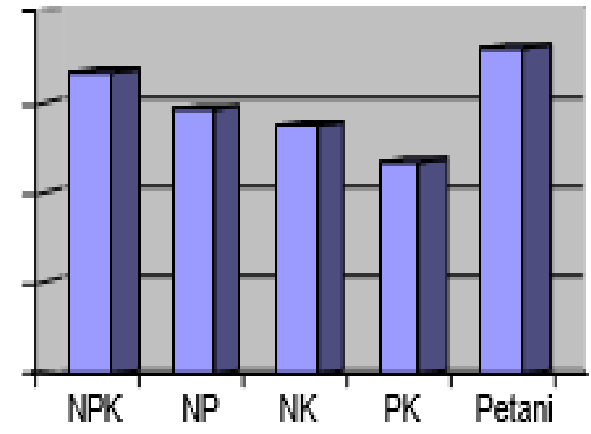

Perlakuan Pemupukan

Gambar 2. Jumlah polong per tanaman

b. Panjang polong

Lain halnya yang terjadi pada panjang polong (Gambar 3) sangat bervariasi yaitu terpanjang dicapai pada perlakuan plot bekas dipupuk dengan NPK dan NP dengan panjang rata-rata $10,26 \mathrm{~cm}$ dan untuk 3 plot perlakuan yang lain masing-masing 9,63 cm, 9,73 $\mathrm{cm}$ dan $9,56 \mathrm{~cm}$.

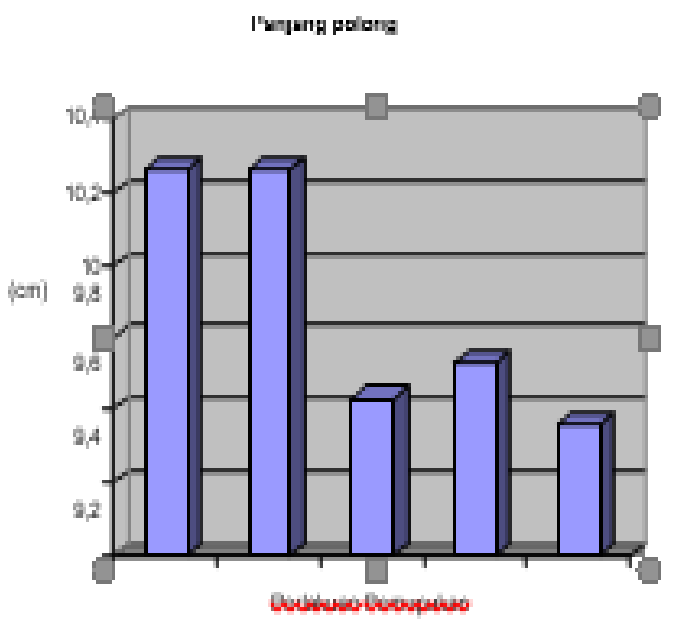

Gambar 3. Panjang polong

c. Jumlah biji per polong

Jumlah biji per polong (Gambar

4) terbanyak dicapai pada plot bekas perlakuan yang dipupuk NPK, NP dan pola petani, masing-masing dengan rata-rata 9,66 biji/polong. Sedang terendah terjadi pada plot bekas dipupuk PK yaitu rata-rata sebanyak $8,33 \mathrm{biji} /$ polong

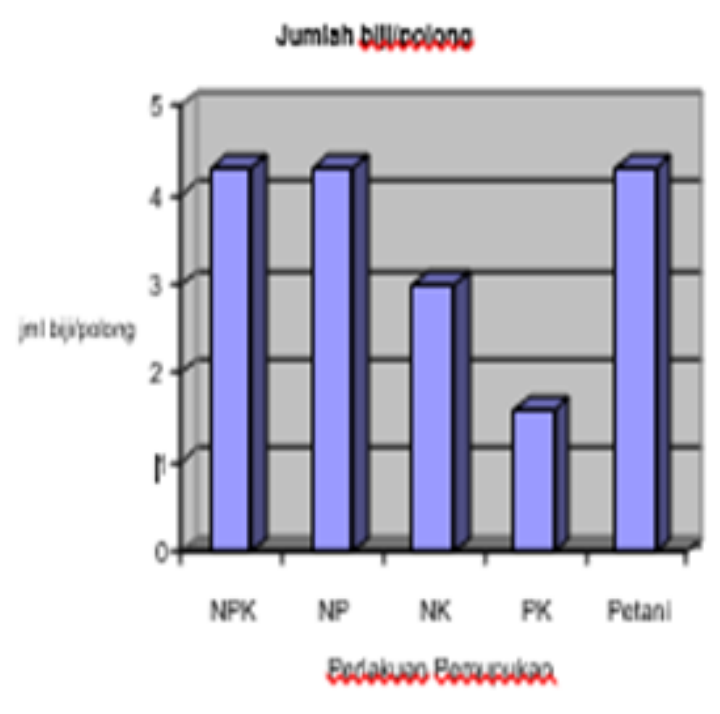

Gambar 4. Jumlah biji polong 
d. Produksi

Produksi kedelai tertinggi setelah dikonversi per hektar dicapai pada plot bekas dipupuk dengan dosis sesuai kebiasaan petani yaitu 1,34 ton/ha, kemudian diikuti pada plot bekas pupuk NPK (1,2 ton/ha), dan masing- masing plot bekas pupuk NP (1,08 ton/ha), plot bekas pupuk NK (0,89 ton/ha) dan 0,76 ton/ha pada plot bekas pupuk PK.

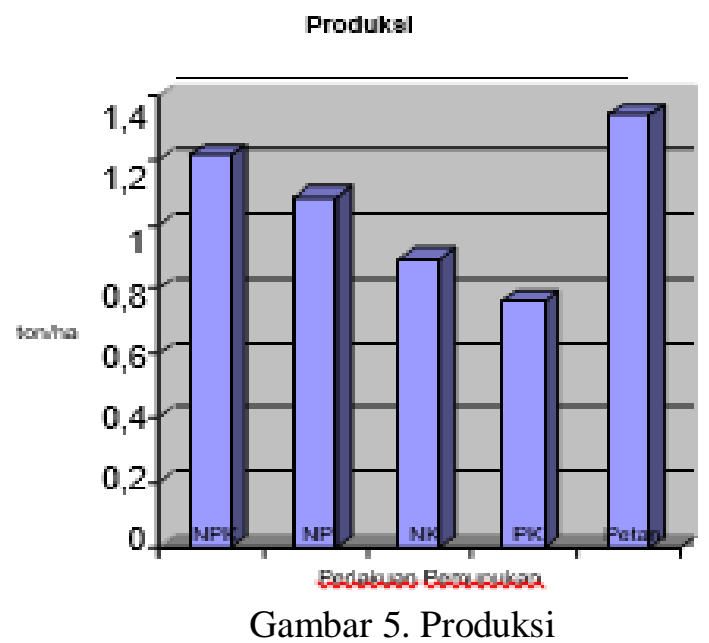

Beragamnya produksi kedelai diduga lebih disebabkan oleh tanggap tanaman terhadap residu pemupukan pada pertanaman padi sebelumnya. Rata-rata tertinggi terjadi pada pertanaman bekas pemupukan pola petani, hal ini diketahui bahwa dosis pupuk yang diberikan petani rata- rata jauh lebih tinggi dibanding pada pola rekomendasi.

Menurut Budhi et al. (1992) ketersediaan unsur hara yang dapat diserap tanaman merupakan salah satu faktor yang mempengaruhi produksi tanaman. Masing- masing jenis tanaman menghendaki jenis dan jumlah unsur hara yang berbeda. Macam dan jumlah unsur hara yang tersedia dalam tanah pada dasarnya harus berada dalam keadaan cukup dan seimbang. Pemupukan $\mathrm{N}$ pada tanaman kedelai pada umumnya tidak memberikan pengaruh yang jelas terhadap kenaikan hasil biji, terutama pada lahan bekas sawah padi. Pemberian pupuk urea pada lahan bekas sawah tidak berpengaruh terhadap komponen hasil dan hasil biji. Terdapatnya bintil akar pada tanaman dapat mengikat $\mathrm{N}$ dari udara dan pengaruh residu pupuk $\mathrm{N}$ dari tanaman padi sebelumnya diduga merupakan faktor tidak responnya kedelai terhadap pemberian pupuk $\mathrm{N}$.

\section{Serangan Hama}

Hasil pengamatan polong yang terserang hama ulat penggerek polong Maruca testuralis (gambar 6), rata-rata berkisar antara 3,6-4,6\%.

Serangan terendah terjadi pada plot bekas perlakuan pupuk NPK dan pola petani, masing-masing 3,6\%. Serangan ini tergolong masih cukup rendah, besar serangan hama penggerek polong tersebut tidak berpengaruh nyata terhadap produksi kedelai. Hal ini diduga karena faktor genetis karena varietas Anjasmoro lebih tahan serangan hama penggerek polong dan aktor lingkungan yaitu pengaruh residu pemupukan yang lengkap menyebabkan tanaman lebih tahan terhadap serangan OPT. 


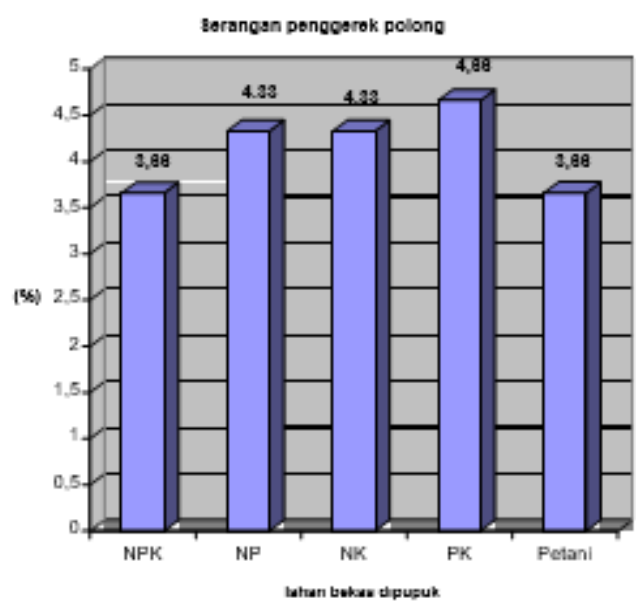

Gambar 6. Serangan penggerek polong.

Dikatakan Marwoto

bahwa kehilangan hasil kedelai akibat serangan hama dapat mencapai $60 \%$ bahkan puso apabila tidak dilakukan tindakan pengendalian. Pendekatan dalam sistem pengendalian hama tanaman kedelai dapat didekati dengan prinsip pengendalian hama terpadu yaitu tanaman sehat, mendayagunakan musuh alami dan pengendalian hama secara rutin sehingga dari hasil pemantauan tersebut akan menentu kan penggunaan komponen pengendaliannya.

\section{KESIMPULAN}

Hasil pengkajian dapat disimpulkan sebagai berikut :

1. Rata-rata pertumbuhan tanaman masa vegetatif pada lokasi bekas dipupuk NPK dan pola petani lebih tinggi, dan pertumbuhan maksimumnya masingmasing adalah $56,33 \mathrm{~cm}$ dan 54,66 $\mathrm{cm}$.

2. Jumlah polong per tanaman tertinggi terjadi pada plot bekas dipupuk sesuai dosis petani diikuti plot bekas pemupukan NPK masing-masing
16,50 dan 15,00 polong/tanaman dengan jumlah biji per polong pada lahan bekas dipupuk NPK dan pola petani adalah 4,66. Rata-rata produksi biji per tanaman tertinggi dicapai pada plot bekas pola petani $(18,4$ g/tanaman), diikuti oleh plot bekas pemupukan NPK (17,13 g/tanaman) atau setara dengan 1,82 ton/ha dan 1,50 ton/ha.

3. Serangan hama ulat penggerek polong rendah yaitu berkisar antara 3,6 - 4,6 $\%$, persentase serangan tersebut tidak berpengaruh nyata terhadap produksi

\section{DAFTAR RUJUKAN}

Astanto Kasno dan Sutarman, T.,. (1992). Perbaikan genetik kedelai untuk stabilitas hasil dalam Monografi Balittan Malang No. 9. Kedelai. Balittan Malang. Hal 25 $-49$.

Astanto Kasno, Marwoto dan Saleh, N., (2002). Inovasi Teknologi Kacang- kacangan dan Umbiumbian. Menjawab tantangan ketahanan pangan nasional. Balitkabi. Malang.

Budhi Santoso Radjit dan T. Adisarwanto. (1993). Teknologi untuk meningkatkan hasil kedelai. Seri Pengembangan No. 23/3/1993. Balittan Malang. 8 halaman.

Marwoto. (1992). Pengendalian hama kedelai dalam Monografi Balittan Malang No. 9. Kedelai. Balittan Malang. Hal 86-9 
Sumarno. (1992). Arti Ekonomis dan

kegunaan kedelai dalam

Monografi Balittan Malang No. 9.

Kedelai. Balittan Malang. Hal 1-

11.

Sunarsedyono, L. Rasmahani, Handoko, Istiqomah, Sunaryo dan Roshid. (2000). Uji adaptasi rakitan teknologi usahatani kedelai. Prosiding Seminar Hasil Penelitian Pengkajian Teknologi Pertanian mendukung Ketahanan Pangan Berwawasan Agribisnis. Malang. Halaman 210-220. 